\title{
UNIVERSIDADE DO ESTADO DO RIO DE JANEIRO
}

\section{FACULDADE DE EDUCAÇÃO DA BAIXADA FLUMINENSE}

\author{
Autores: Fabio Pereira / Gabriel Bernini / Israel Ondas / Luis Alberto / Marcio \\ Bertoni / Vander Alves
}

\section{ÁREAS DE PROTEÇÃO AMBIENTAL NA BAIXADA FLUMINENSE}

O que é uma área de proteção ambiental?

No Brasil, uma área de proteção ambiental (APA) é uma área em geral extensa, com certo grau de ocupação humana, dotada de atributos abióticos, bióticos, estéticos ou culturais especialmente importantes para a qualidade de vida e o bem-estar das populações humanas, e tem como objetivos básicos proteger a diversidade biológica, disciplinar o processo de ocupação e assegurar a sustentabilidade do uso dos recursos naturais.

O que é área de preservação permanente?

Área de Preservação Permanente (APP) é, segundo o Código Florestal Brasileiro, toda área enquadrada nos artigos $2^{\circ}$ e $3^{\circ}$ da Lei $n^{\circ} 4.771$, [1] coberta ou não por vegetação nativa, com a função ambiental de preservar os recursos hídricos, a paisagem, a estabilidade geológica, a biodiversidade, o fluxo gênico de fauna e flora, proteger o solo e assegurar o bem-estar das populações humanas.

A supressão total ou parcial de vegetação em área de preservação permanente requer prévia autorização do Poder Executivo Federal, e só pode ser autorizada em caso de necessidade, devidamente caracterizada em procedimento administrativo próprio, visando à execução de obras ou atividades de utilidade pública ou interesse social, e quando não houver alternativa técnica e locacional ao empreendimento proposto.

\section{APA de Guapimirim}

A APA de Guapimirim abrange praticamente a última região de manguezais da orla da Baia de Guanabara. Desempenha um relevante papel na retenção dos sedimentos que contribuem para 
assorearem a Baia, contribuindo para a manutenção da taxa de produtividade das águas estuarinas que ainda hoje, através do produto da pesca artesanal, representa o sustento de inúmeras famílias da região.

Além de manguezais, a APA Guapimirim compreende igualmente regiões ocupadas por atividades agrícolas e zonas urbanas, que são compostas por pequenos núcleos de pescadores, agricultores e população de baixa renda. Além disso, é importante destacar as atividades relacionadas que vem aumentando a utilização subaquática do norte da Baía de forma ambientalmente irresponsável, pois volta e meio algum vazamento acontece podendo causar danos sérios aos manguezais.

HISTÓRIA: Um movimento ambientalista organizado, o qual participaram diversos vários representantes da sociedade civil e da comunidade científica, em prol da preservação dos manguezais que vinham sendo destruídos exorbitantemente no Estado do Rio de Janeiro e em todo país, resultou na criação da APA de Guapimirim objetivando proteger suas partes remanescentes no recôncavo da Baía de Guanabara englobando partes dos municípios de Magé, Guapimirim, Itaboraí e São Gonçalo.

CARACTERÍSTICAS: A APA de Guapimirim possui uma área de 138,25Km2, sendo 44\% do seu território formado por manguezais em situações diferentes em relação a conservação e regeneração.Ocupando a região costeira esta região é banhada pelos cursos finais dos rios Suruí, Iriri, Roncador, Guapimirim, Caceribú e Guaxindiba fazendo desta localidade a principal fornecedora de água fluvial na baía com 70\%. Vale destacar também que este é o último reduto contínuo desse tipo de ecossistema na Baía de Guanabara.

\section{APA do rio Tinguá/Iguaçú}

A Reserva Biológica Federal do Tinguá é uma reserva biológica brasileira. Estende-se por uma área de 26 mil hectares e abrange seis municípios, sendo a maior parte dentro do município de Nova Iguaçu. Em 1997 a reserva foi declarada Patrimônio da Humanidade pela Unesco e está incluída na reserva da biosfera da Mata Atlântica.

A região mais alta da reserva atinge os 1600 metros de altitude, sendo possível avistá-la de toda a extensão do município.

No seu interior, em local não aberto à visitação pública, encontram-se as ruínas da freguesia de Santana das Palmeiras, povoação que foi abandonada no final do século XIX.

Hoje a reserva está fortemente ameaçada por caçadores que matam animais silvestres para 
vender carnes exóticas ou os capturam para inclusive exportar. Grandes empresas poluidoras contribuem para a degradação ambiental. Existe até um aterro sanitário, que beira a reserva, onde ilegalmente foram despejados resíduos altamente tóxicos. A população que vive em torno da reserva tem problemas com a contaminação do lençol d'água que consome.

\section{Parque Municipal da Caixa D'água}

O Parque Municipal da Caixa D’água possui sua lei de criação a partir do decreto Municipal n 2238 do ano 1991. Ela tem este nome por possuir uma estrutura arredondada (caixa d'água), que servia para armazenagem de água para as residências locais. Está localizada no Segundo Distrito do Município de Duque de Caxias, no bairro Jardim Primavera, próximo a sede da Prefeitura da cidade. Portanto, ela está localizada em uma área urbana, e a população está aumentando, ocorrendo à diminuição de sua área.

CARACTERÍSTICAS: Possui vegetação descaracterizada no entorno da caixa d'água abandonada devido ao alto nível de degradação e alguns lampejos de reflorestamento feitos pela secretaria do meio ambiente. No verão, as regiões mais baixas são alagadas com freqüência devido ao sistema do lençol freático que aflora proveniente dos maciços em volta.

\section{APA Gericinó Mendanha}

A APA de Gericinó/Mendanha teve sua criação autorizada pela a Lei Estadual 1.331, de 12 de julho de 1988, e foi efetivamente implantado pelo Decreto $\mathrm{n}^{\mathrm{o}} 38.183$, de 05 de setembro de 2005. Sua área abrange território ocupado pelas serras de Madureira, Marapicu, Gericinó e Mendanha. O maciço do Gericinó inclui o Morro do Marapicu e as Serras do Mendanha, do Gericinó e de Madureira - influi nos microclimas do seu entorno, seja pelo relevo, que atua como barreira à passagem de ventos e de massas úmidas, seja pela presença das matas, que contribuem para a absorção de calor e para o nível de umidade do ar. A vegetação original da APA do GericinoMendanha é composta pala Mata Atlântica, que ao longo dos anos foi sendo devastada pelo intenso processo de ocupação humana, através da expansão das atividades rurais e urbanas, que foram modificando a sua paisagem.

A APA Estadual Gericinó-Mendanha tem sua proteção ambiental vinculada a elementos de relevância física e natural, tais como as estruturas geológicas vulcânicas (vulcão de Nova Iguaçu e Chaminé Lamego), as duas grandes bacias hidrográficas da Guanabara e Baía de Sepetiba, os 
sistema de Rios do Guandu, Iguaçu e Sarapuí, as florestas remanescentes de Mata Atlântica, detentora de uma grande diversidade biológica (fauna e flora) e outros recursos naturais. Os atrativos da APA Estadual Gericinó Mendanha variam desde as belas cachoeiras, poços naturais, trilhas, grutas, rampa de vôo livre, rapel na Pedra da Cotenda, alguns sítios históricos e, com destaque, a cratera do vulcão de Nova Iguaçu.

Bibliografia:

http://pt.scribd.com/doc/8972249/Diagnostico-das-Unidades-de-Conservacao-de-Nova-Iguacu-em2005

http://www4.icmbio.gov.br/apaguapimirim//?id_menu=2

http://www.nima.puc-rio.br/sobre_nima/projetos/caxias/mapas_novos/apas_ucs_DC.pdf

http://www.nima.puc-rio.br/noticias/livro_educacao_ambiental_duque_de_caxias.pdf PAG.26

http://www.inea.rj.gov.br/apa/apa_gericino_mendanha.asp

WIKIPÉDIA

http://www.bvambientebf.uerj.br/ 